\title{
Educational program on continuous quality improvement for pediatric residents
}

\author{
María N. Carozza Colombini, M.D. ${ }^{a}$, Carolina Silva, M.D. ${ }^{a}$, Milena Luiz Passarela, M.D. ${ }^{a}$, \\ Carolina Arzelan Clerici, M.D. ${ }^{a}$ and Julián Llera, M.D. ${ }^{a}$
}

\begin{abstract}
Health care providers' involvement is critical for quality of care improvement. Nevertheless, most residency programs do not include this topic. The objective is to describe an educational experience on quality of care improvement for residents. The development of an improvement cycle was included in the second year syllabus of the pediatric residency program. A handbook and an online course were provided. Over 12 months, 10 proposals were designed on therapeutic and diagnostic approaches, effective communication, patient admission and logistics; they were based on sentinel events, incident reports, direct observation, and patients' complaints. Multidisciplinary working teams were formed. Health care protocols were agreed and processes were standardized.

A program based on educational goals for continuous quality improvement allowed residents to acquire theoretical training and practical experience on the topic.

Key words: health care quality, quality improvement, medical education, internship and residency.
\end{abstract}

http:/ / dx.doi.org/10.5546/ aap.2020.eng.286

To cite: Carozza Colombini MN, Silva C, Luiz Passarela M, Arzelan ClericiC, Llera J.Educational program on continuous quality improvement for pediatric residents. Arch Argent Pediatr 2020;118(4):286289.

a. Department of Clinical Pediatrics and Instituto Universitario, Hospital Italiano de Buenos Aires, Argentina.

E-mail address: María N. Carozza Colombini, M.D.: maria.carozza@ hospitalitaliano.org.ar

Funding:

None.

Conflict of interest:

None.

Received: 5-2-2019

Accepted: 11-4-2019

\section{INTRODUCTION}

Continuous quality improvement (CQI) in health care involves a set of systematic activities, designed to bring about immediate and positive changes in health care. ${ }^{1}$ The objective of quality improvement initiatives is to bridge the gap between best practices and current health care practices, ${ }^{2}$ understanding the former ones as those that are safe, timely, effective, efficient, equitable, and patient-centered. ${ }^{3}$
The systematic approach of CQI includes action cycles that start with obtaining data about an event and identifying an improvement area, followed by the implementation of changes that lead to measurable progress in health care or in the population's health status. Efforts should be centered on finding the most effective methods and factors to facilitate quality improvement. ${ }^{4}$ There are several reasons why this is important, including the identification and reduction of medical errors, the optimization of health care effectiveness, resource use efficiency, outcome improvement, and the alignment of health care with patients' interests. ${ }^{5}$

In spite of its great importance, health care quality is not usually included in graduate medical education, at least in Argentina, and students and physicians who are still undergoing training are often not able to recognize the significance of these skills for their careers. ${ }^{6}$ Health care providers' growing participation is critical in order to make a significant impact on the quality of care offered to a large number of patients. Incorporating residents in CQI programs, which include training on the subject matter and the development of analysis and improvement strategies, as well as their participation in hospitals' quality committees, has shown positive results. ${ }^{2}$ To date, there are no local studies regarding the implementation of CQI strategies on residency programs.

\section{OBJECTIVE}

To describe an educational experience on health care quality for residents and their participation in improvement projects, with the first results of this initiative. 


\section{MATERIALS AND METHODS}

Our institution is a tertiary care teaching hospital. Since 2015, it has been certified as an academic hospital by the Joint Commission International, which assesses health care quality and safety, as well as teaching and research activities, based on the most demanding international standards. The Division of Clinical Pediatrics receives approximately 150000 outpatient visits and 5000 hospitalizations each year. In its two facilities, there are currently 45 pediatric residents from different years undergoing training.

The Pediatric Day Hospital was created 25 years ago to meet the needs of patients with complex problems, in order to bring together, in time and space, clinical assessment and necessary interdisciplinary and technological resources. It also receives patients who require diagnostic and therapeutic procedures with few hours of hospitalization. Even though patients with a great variety of conditions are seen, routine processes are highly standardized and reproducible. Pediatric residents rotate at the Day Hospital for one month during their first year of training and for two months during their second year.

In 2018, the development of problem identification strategies and the design of improvement cycles during the second year of rotation at the Day Hospital were included in the syllabus of the pediatric residency program. To this end, a quality management handbook was developed, which included materials from the Ministry of Health ${ }^{5}$ and from our institution's Quality Department. Moreover, before starting their rotation at the Day Hospital, second-year residents were asked to take an online course on quality improvement offered by the Institute for Healthcare Improvement. ${ }^{7}$

The objective of this initiative is that secondyear residents identify an improvement opportunity in the first month of rotation at the Day Hospital. The problem or aspect to be improved should be related to health care processes; data should be available in patients' electronic medical records and it should not entail structural changes.

According to the program, each resident has a mentor (a staff physicians from the Division of Clinical Pediatrics) to guide them in the development of the improvement cycle. After identifying the problem, the resident should gather data related to the process and analyze them. Consequently, they should form a task force with physicians from the Division of Clinical Pediatrics and from the other involved specialties, nurses, administrative staff, and employees from other areas, such as the Hospitality, Housekeeping/Cleaning, and Nursing departments. Together with this team, they should design an improvement proposal.

During the second month of rotation, the resident works on implementing the proposed improvement cycle. To this end, they share educational materials and gather with representatives from the involved departments in order to cause the change; the resident then analyzes the process and makes a report with post-implementation results. During the following months, after finishing their rotation at the Day Hospital, residents commit themselves to doing a follow-up of their improvement cycle and reviewing data every six months. Depending on these findings, changes, new meetings, and communication reinforcement may take place.

\section{RESULTS}

During 12 months, between March 2018 and March 2019, second-year pediatric residents who rotated at the Day Hospital took and passed the quality improvement course. ${ }^{8}$ Ten quality improvement proposals were formulated, and two others are still in process.

Annex describes the main characteristics of these projects. Different health care areas were covered, including therapeutic approaches, diagnostic approaches, effective communication among providers, patient admission and bed management, and logistics for the transport of biological samples. Proposals were based on sentinel events, incident reports, residents' direct observation of processes, and patients' and relatives' complaints, which hindered the recording of measurements prior to the development of some projects.

For these improvement cycles, 10 working teams were formed, with an average of 4 to 5 participants in each team. The Department of Clinical Pediatrics was included in all of them. The Quality Department, the departments of Gastroenterology, Hematology, Transfusion Medicine and Pediatric Surgery, the Nursing Department, Patient Admission, administrative staff from the hospital internal transport, and the Housekeeping/Cleaning and Hospitality departments also took part in different projects.

A protocol on the premedication for blood products was developed due to the lack of 
indication guidelines and their heterogeneity. Four months after it was set out and implemented, $84 \%$ compliance was observed within the health care team.

Based on a sentinel event related to a dosing error of polyethylene glycol for bowel preparation and given the lack of a standardized protocol for this process, a guide with recommendations was developed. Six months after its implementation, $69 \%$ compliance was achieved, and nonadherence was higher among outpatients when compared to inpatients, $78 \%$ versus $22 \%$, respectively.

As a result of complaints from relatives regarding delays in discharges of patients admitted for $\mathrm{pH}$-metry, discharge time was measured 6 months before and 3 months after the implementation of the improvement cycle. There was a 2.23-hour reduction in the mean discharge time, and $90 \%$ of discharges took place before noon. Based on this, new meetings were held with different departments to report results and continue with improvement strategies. Besides, the educational goal of developing an improvement cycle was attained by the 7 remaining residents; 3 had no measurements and 4 were at the preimplementation stage.

\section{DISCUSSION}

CQI requires the motivation and daily experience of all providers involved in the clinical practice in order to identify ways to optimize health care, implement small-scale changes, gather data regarding the effect of such changes, and assess results. ${ }^{1}$ It is essential that physicians are trained on this area and actively participate in improvement projects during their professional careers. In our experience, by including topics related to health care quality in the residency syllabus, physicians who were undergoing training were able to propose an improvement cycle, formulate strategies, and cause changes. Even though these are preliminary results, favorable changes have been observed in different aspects related to patient care, including not only medical behaviors -such as prescribing different drugsbut also improvements in patient distribution at the Day Hospital, bed management, and discharge times.

In the past two decades, CQI has become a priority in the training and certification of health care providers and of the institutions where they work. Present and future generations of physicians are expected to be experts compared to their predecessors. ${ }^{2}$ In some countries, CQI and patient safety principles are curriculum requirements for residency programs, ${ }^{8}$ and they are also included in the requirements set by the Joint Commission International and the Accreditation Council for Graduate Medical Education (ACGME) in the United States. ${ }^{9,10}$ Nevertheless, even though there are other initiatives in some centers, CQI is still not part of the syllabus in most of Argentina's medical university degrees and residency programs.

The experience presented here, in addition to promoting the implementation of health care quality improvement cycles, also allowed residents to acquire theoretical training and practical experience on the topic. They could provide a valuable perspective on the workflow of different areas and problems. In this case, not only did they make proposals, but they also trained other residents and changed the usual practices or processes of physicians with more years of training and of other health care team members. In the future, it would be important to assess the impact of this initiative on participating residents. In previously published studies, residents who took part of quality programs improved their self-perception regarding CQI knowledge and reported feeling satisfied and useful for the project. 2,11,12

Other similar initiatives have observed that, in order to promote a bottom-up approach, it is necessary for physicians still undergoing training to be committed. Nevertheless, to ensure effectiveness, supervisors' and authorities' endorsement is required, i.e. a top-down approach. ${ }^{13}$ In our case, compliance with proposals by the entire health care team may have been favored by the fact that they were designed by residents themselves. The motivation provided by leaders by creating a quality department and designing an institutional project focused on the continuous improvement of health care processes was also important.

Based on this proposal, and taking as a starting point an educational goal from the residency program, it was possible to involve all health care team members, including residents and specialists, nurses, administrative staff, and other workers from the hospital. This led to a multiplying effect on the organizational culture and the identification of many improvement opportunities. 


\section{CONCLUSION}

The design and implementation of a CQI program in residents' training by means of clear educational goals based on theoretical learning and tools for the analysis of the health care context are presented in this article. This first approach, with a multidisciplinary team and guided by a mentor, allowed residents to acquire theoretical training and practical experience in health care quality.

\section{REFERENCES}

1. Margolis P, Provost LP, Schoettker PJ, Britto MT. Quality improvement, clinical research, and quality improvement research opportunities for integration. Pediatr Clin North Am. 2009; 56(4):831-41.

2. Freed GL, De Jong N, Macy ML, Van KD, etal. Pediatricians' participation in quality improvement at the time of enrollment in MOC. Pediatrics. 2018; 142(5):e20180712.

3. Committee on Quality of Health Care in America, Institute of Medicine. Crossing the Quality Chasm: A New Health System for the $21^{\text {st }}$ Century. Washington DC: National Academies Press; 2001.

4. The Health Foundation. Evidence scan: Improvement science. London, 2011. [Accessed on: February 11 ${ }^{\text {th }}$, 2019]. Available at: www.health.org.uk/publications/ improvement-science.

5. Martínez Sagasta C. Estandarización de los Procesos Asistenciales. Calidad en la Gestión clínica. Buenos Aires: Ministerio de Salud de la Nación; 2007.
6. Demirdjian G, Rodríguez S, Vassallo JC, Irazola V, et al. Capacitación hospitalaria de profesionales pediátricos en investigación y gestión. Arch Argent Pediatr. 2017; 115(1):58-64.

7. Institute for Healthcare Improvement Open School. Curso en línea. Mejora de la calidad. Washington DC, 2011. [Accessed on: February 11 ${ }^{\text {th }}$, 2019]. Available at: http:// www.ihi.org/education/IHIOpenSchool/Chapters / Groups / LAC/Pages / Cursos-en-L\%C3\%ADnea.aspx.

8. Abrahan D, Cobb H, Murphy M, Straub DM. Improving the Quality of a Quality Improvement and Patient Safety Curriculum in a Pediatric Residency Program. Pediatrics. 2018; 141(1 Meeting Abstracts):140.

9. Tomolo AM, Lawrence RH, Aron DC. A case study of translating ACGME practice-based learning and improvement requirements into reality: systems quality improvement projects as the key component to a comprehensive curriculum. Qual Saf Health Care. 2009; 18(3):217-24.

10. Blum $A B$, Shea $S$, Czeisler $C A$, Landrigan $C P$, et al. Implementing the 2009 Institute of Medicine recommendations on resident physician work hours, supervision, and safety. Nat Sci Sleep. 2011; 3:47-85.

11. Wong BM, Goguen J, Shojania KG. Building capacity for quality: a pilot co-learning curriculum in quality improvement for faculty and resident learners. J Grad Med Educ. 2013; 5(4):689-93.

12. DuelloK, LouhI, Greig H, Dawson N. Residents' knowledge of quality improvement: the impact of using a group project curriculum. Postgrad Med J. 2015; 91(1078):431-5.

13. Moriates C, Wong BM. High-value care programmes from the bottom-up... and the top-down. BMJ Qual Saf. 2016; 25(11):821-3. 


\section{ANNEX}

\section{Characteristics of the improvement cycles developed by residents}

\begin{tabular}{|c|c|c|c|c|c|}
\hline $\begin{array}{l}\text { Improvement } \\
\text { cycle }\end{array}$ & Area & Rationale & Team composition & $\begin{array}{l}\text { Implementation } \\
\text { strategies }\end{array}$ & Current status \\
\hline $\begin{array}{l}\text { Recommendations } \\
\text { for bowel } \\
\text { preparation in } \\
\text { pediatrics. }\end{array}$ & $\begin{array}{l}\text { Therapeutic } \\
\text { approach. }\end{array}$ & $\begin{array}{c}\text { Sentinel event: } \\
\text { patient with seizures } \\
\text { secondary to } \\
\text { hyponatremia due to } \\
\text { an incorrect } \\
\text { polyethylene glycol } \\
\text { dose. }\end{array}$ & $\begin{array}{l}\text { - Clinical Pediatrics: } \\
\text { second-year resident and } \\
\text { coordinating physician of } \\
\text { the Day Hospital. } \\
\text { - Pediatric } \\
\text { Gastroenterology. } \\
\text { - Pediatric Surgery. } \\
\text { - Nursing Department. } \\
\text { - Pharmacy Department. }\end{array}$ & \begin{tabular}{|l|} 
- Development of a \\
protocol with \\
recommendations for \\
bowel preparation before \\
procedures. \\
- Dissemination among \\
residents and staff \\
physicians from Clinical \\
Pediatrics.
\end{tabular} & $\begin{array}{l}\text { Implemented. } \\
69 \% \\
\text { compliance. } \\
\text { Adequate } \\
\text { colonic } \\
\text { preparation in } \\
80 \% \text { of cases. }\end{array}$ \\
\hline $\begin{array}{l}\text { Recommendations } \\
\text { for } \\
\text { premedication } \\
\text { in blood } \\
\text { transfusions. }\end{array}$ & $\begin{array}{l}\text { Therapeutic } \\
\text { approach. }\end{array}$ & $\begin{array}{l}\text { Direct observation: } \\
\text { heterogeneous } \\
\text { medication } \\
\text { prescriptions before } \\
\text { transfusions among } \\
\text { different treating } \\
\text { physicians. }\end{array}$ & $\begin{array}{l}\text { - Clinical Pediatrics: } \\
\text { second-year resident and } \\
\text { coordinating physician of } \\
\text { the Day Hospital. } \\
\text { - Hemotherapy. } \\
\text { - Pediatric Hematology. } \\
\text { - Nursing Department. }\end{array}$ & $\begin{array}{l}\text { - Development of a } \\
\text { protocol with medication } \\
\text { recommendations before } \\
\text { blood product } \\
\text { transfusions. } \\
\text { - Dissemination among } \\
\text { residents and staff } \\
\text { physicians from Clinical } \\
\text { Pediatrics. }\end{array}$ & $\begin{array}{c}\text { Implemented. } \\
84 \% \\
\text { compliance. }\end{array}$ \\
\hline $\begin{array}{l}\text { Discharge time } \\
\text { among patients } \\
\text { with a 24-h pH } \\
\text { measurement. }\end{array}$ & $\begin{array}{c}\text { Patient } \\
\text { admission and } \\
\text { bed } \\
\text { management. }\end{array}$ & $\begin{array}{c}\text { Relatives' complaints } \\
\text { due to long waiting } \\
\text { hours. }\end{array}$ & $\begin{array}{l}\text { - Clinical Pediatrics: } \\
\text { second-year resident and } \\
\text { coordinating physician of } \\
\text { the Day Hospital. } \\
\text { - Pediatric } \\
\text { Gastroenterology. } \\
\text { - Patient Admission. } \\
\text { - Hospitality and } \\
\text { Housekeeping/Cleaning. } \\
\text { - Nursing Department. }\end{array}$ & $\begin{array}{l}\text { - Optimizing the removal } \\
\text { time of the pH meter. } \\
\text { - Development of a } \\
\text { discharge summary } \\
\text { template to optimize } \\
\text { discharge. } \\
\text { - Dissemination among } \\
\text { residents and staff } \\
\text { physicians from Clinical } \\
\text { Pediatrics, Nursing, } \\
\text { Patient Admission, and } \\
\text { Hospitality and } \\
\text { Housekeeping/Cleaning. }\end{array}$ & $\begin{array}{l}\text { Implemented. } \\
\text { A 2.23-hour } \\
\text { reduction in } \\
\text { mean } \\
\text { discharge } \\
\text { time. }\end{array}$ \\
\hline $\begin{array}{c}\text { Transfer of care } \\
\text { between the } \\
\text { Pediatric } \\
\text { Emergency } \\
\text { Department and } \\
\text { the Inpatient } \\
\text { Ward. }\end{array}$ & $\begin{array}{c}\text { Effective } \\
\text { communication. }\end{array}$ & $\begin{array}{l}\text { Direct observation: } \\
\text { variability in verbal } \\
\text { handoff contents } \\
\text { between the } \\
\text { physician in charge of } \\
\text { the patient at the } \\
\text { Emergency } \\
\text { Department and the } \\
\text { physician from the } \\
\text { Inpatient Ward. }\end{array}$ & $\begin{array}{l}\text { - Clinical Pediatrics: } \\
\text { second-year resident and } \\
\text { coordinating physician of } \\
\text { the Day Hospital, intern } \\
\text { physicians from the } \\
\text { Pediatric Emergency Room } \\
\text { and the Inpatient Ward, } \\
\text { heads of residents. } \\
\text { - Quality Department. }\end{array}$ & $\begin{array}{l}\text { - Development of a } \\
\text { preformed template with } \\
\text { relevant information for } \\
\text { the transfer of care. } \\
\text { - Dissemination among } \\
\text { residents and staff } \\
\text { physicians from Clinical } \\
\text { Pediatrics. }\end{array}$ & $\begin{array}{l}\text { Implemented. } \\
\text { Result } \\
\text { measurement } \\
\text { is still pending. }\end{array}$ \\
\hline
\end{tabular}




\begin{tabular}{|c|c|c|c|c|c|}
\hline $\begin{array}{l}\text { Improvement } \\
\text { cycle }\end{array}$ & Area & Rationale & Team composition & $\begin{array}{l}\text { Implementation } \\
\text { strategies }\end{array}$ & Current status \\
\hline $\begin{array}{l}\text { Effective } \\
\text { transport of } \\
\text { Anatomic } \\
\text { Pathology and } \\
\text { Nuclear } \\
\text { Medicine } \\
\text { samples. }\end{array}$ & Logistics. & $\begin{array}{l}\text { Incident report: delay } \\
\text { in specimen } \\
\text { submission that } \\
\text { resulted in another } \\
\text { hospitalization in } \\
\text { order to repeat the } \\
\text { test. }\end{array}$ & $\begin{array}{l}\text { - Clinical Pediatrics: } \\
\text { second-year resident and } \\
\text { coordinating physician of } \\
\text { the Day Hospital. } \\
\text { - Nursing Department. } \\
\text { - Internal transport within } \\
\text { the hospital. }\end{array}$ & $\begin{array}{l}\text { - Design of a sample } \\
\text { transport strategy } \\
\text { through internal } \\
\text { transport within the } \\
\text { hospital. } \\
\text { - Dissemination among } \\
\text { residents and staff } \\
\text { physicians from Clinical } \\
\text { Pediatrics. }\end{array}$ & $\begin{array}{l}\text { Implemented. } \\
\text { Result } \\
\text { measurement } \\
\text { is still pending. }\end{array}$ \\
\hline $\begin{array}{c}\text { Distribution of } \\
\text { patients in the } \\
\text { weekly schedule } \\
\text { of the Pediatric } \\
\text { Day Hospital. }\end{array}$ & $\begin{array}{l}\text { Patient } \\
\text { admission and } \\
\text { bed } \\
\text { management. }\end{array}$ & $\begin{array}{l}\text { Direct observation: } \\
\text { variability in the } \\
\text { number of scheduled } \\
\text { hospitalizations on } \\
\text { different days of the } \\
\text { week. Relatives' } \\
\text { complaints due to } \\
\text { long waiting hours. }\end{array}$ & $\begin{array}{l}\text { - Clinical Pediatrics: } \\
\text { second-year resident and } \\
\text { coordinating physician of } \\
\text { the Day Hospital. } \\
\text { - Patient Admission. } \\
\text { - Administrative staff from } \\
\text { the Pediatric Day Hospital. } \\
\end{array}$ & $\begin{array}{l}\text { - Scheduling } \\
\text { hospitalizations for IV } \\
\text { drug infusion and } \\
\text { diagnostic tests on the } \\
\text { days of the week with the } \\
\text { least procedures. } \\
\text { - Dissemination among } \\
\text { the administrative staff, } \\
\text { residents and staff } \\
\text { physicians from Clinical } \\
\text { Pediatrics. }\end{array}$ & $\begin{array}{l}\text { Implemented. } \\
\text { Result } \\
\text { measurement } \\
\text { is still pending. }\end{array}$ \\
\hline $\begin{array}{c}\text { Recommendations } \\
\text { for patient } \\
\text { handoff among } \\
\text { health care } \\
\text { team members } \\
\text { during } \\
\text { hospitalization. }\end{array}$ & $\begin{array}{c}\text { Effective } \\
\text { communication. }\end{array}$ & $\begin{array}{l}\text { Direct observation: } \\
\text { variability in handoff } \\
\text { contents during } \\
\text { hospitalization. }\end{array}$ & $\begin{array}{l}\text { - Clinical Pediatrics: } \\
\text { second-year resident and } \\
\text { coordinating physician of } \\
\text { the Day Hospital, intern } \\
\text { physicians from the } \\
\text { Pediatric Ward, heads of } \\
\text { residents. } \\
\text { - Quality Department. }\end{array}$ & \begin{tabular}{|l|} 
- Development of a \\
preformed template with \\
relevant information for \\
the handoff. \\
- Dissemination among \\
residents and staff \\
physicians from Clinical \\
Pediatrics.
\end{tabular} & $\begin{array}{c}\text { Under } \\
\text { development. }\end{array}$ \\
\hline $\begin{array}{c}\text { Preoperative } \\
\text { assessment } \\
\text { among pediatric } \\
\text { outpatients. }\end{array}$ & $\begin{array}{l}\text { Diagnostic } \\
\text { approach. }\end{array}$ & $\begin{array}{l}\text { Incident report: } \\
\text { patients admitted for } \\
\text { procedures to the } \\
\text { Day Hospital without } \\
\text { a complete } \\
\text { preoperative } \\
\text { assessment. }\end{array}$ & $\begin{array}{l}\text { - Clinical Pediatrics: } \\
\text { second-year resident, } \\
\text { coordinating physician of } \\
\text { the Day Hospital. } \\
\text { - Team in charge of } \\
\text { preoperative assessment. }\end{array}$ & $\begin{array}{l}\text { - Meetings with the } \\
\text { preoperative team from } \\
\text { the outpatient area to } \\
\text { standardize criteria. } \\
\text { - Dissemination among } \\
\text { residents and staff } \\
\text { physicians from Clinical } \\
\text { Pediatrics. }\end{array}$ & $\begin{array}{c}\text { Under } \\
\text { development. }\end{array}$ \\
\hline $\begin{array}{l}\text { Preoperative } \\
\text { care for } \\
\text { scheduled bile- } \\
\text { duct } \\
\text { interventions in } \\
\text { transplanted } \\
\text { patients. }\end{array}$ & $\begin{array}{l}\text { Therapeutic } \\
\text { approach. }\end{array}$ & $\begin{array}{l}\text { Sentinel event: two } \\
\text { patients with severe } \\
\text { complications } \\
\text { associated with pre- } \\
\text { intervention care, } \\
\text { who required } \\
\text { intensive care and } \\
\text { hemodynamic } \\
\text { support. }\end{array}$ & \begin{tabular}{|l|} 
- Clinical Pediatrics: \\
second-year resident, head \\
of department. \\
- Gastroenterology and \\
Pediatric Hepatology. \\
- Pediatric Endocrinology. \\
- General Surgery. \\
- Anesthesiology. \\
- Pediatric Infectious \\
Diseases. \\
- Nursing Department.
\end{tabular} & $\begin{array}{l}\text { - Root-cause analysis of } \\
\text { sentinel events. } \\
\text { - Development of } \\
\text { recommendations for } \\
\text { preoperative } \\
\text { management in } \\
\text { transplanted patients. }\end{array}$ & $\begin{array}{c}\text { Under } \\
\text { development. }\end{array}$ \\
\hline $\begin{array}{c}\text { Management of } \\
\text { tracheostomized, } \\
\text { chronically } \\
\text { ventilated } \\
\text { children, with a } \\
\text { short } \\
\text { hospitalization } \\
\text { at the Pediatric } \\
\text { Day Hospital. }\end{array}$ & $\begin{array}{c}\text { Patient } \\
\text { admission and } \\
\text { bed } \\
\text { management. } \\
\text { Therapeutic } \\
\text { approach. }\end{array}$ & $\begin{array}{l}\text { Incident report: } \\
\text { patients with } \\
\text { scheduled } \\
\text { hospitalizations } \\
\text { admitted to the } \\
\text { Pediatric Emergency } \\
\text { Department due to a } \\
\text { lack of physical and } \\
\text { human resources for } \\
\text { their care at the Day } \\
\text { Hospital. }\end{array}$ & $\begin{array}{l}\text { - Clinical Pediatrics: } \\
\text { second-year resident, } \\
\text { physician of the Day } \\
\text { Hospital. } \\
\text { - Pediatric Emergency } \\
\text { Department. } \\
\text { - Pediatric Pulmonology. } \\
\text { - Pediatric Chest } \\
\text { Physiotherapy. } \\
\text { - Nursing Department. } \\
\text { - Patient Admission. }\end{array}$ & $\begin{array}{l}\text { - Reviewing and } \\
\text { equipping the physical } \\
\text { space for the care of } \\
\text { chronically ventilated } \\
\text { patients. } \\
\text { - Training health care } \\
\text { providers and nurses } \\
\text { from the area on the use } \\
\text { of domiciliary ventilators. }\end{array}$ & $\begin{array}{c}\text { Under } \\
\text { development. }\end{array}$ \\
\hline
\end{tabular}

